\title{
Lamprophyric dykes in Revdal, Scoresby Land, East Greenland: conflicting field observations and K-Ar age determinations
}

\author{
POUL-HENRIK LARSEN, LARS STEMMERIK, TROELS F.D. NIELSEN \& DAVID C. REX
}

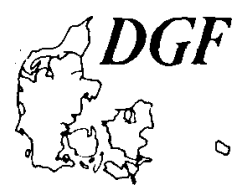

Larsen, P.-H., Stemmerik, L., Nielsen, T.F.D. \& Rex, D.C.: Lamprophyric dykes in Revdal, Scoresby
Land, East Greenland: conflicting field observations and K-Ar age determinations. Bull. geol. Soc.
Denmark, vol. 38, pp. 1-9, Copenhagen, April 25th, 1990. https://doi.org/10.37570/bgsd-1990-38-01

Field observations on lamprophyric dykes in Revdal, Scoresby Land, suggest a Late Permian age and the dykes would thus represent magmatism related to Permian rifting and basin formation, whereas K-Ar age determinations and chemistry suggest a Tertiary age. It is concluded that the dykes probably are Tertiary and never penetrated Upper Permian sediments due to chilling and fracturing at the base of Upper Permian water rich sediments. The dykes most likely belong to a period of alkaline magmatism that followed the onset of sea floor spreading in this part of the North Atlantic around $55 \mathrm{Ma}$ ago.

Poul-Henrik Larsen, Lars Stemmerik and Troels F.D. Nielsen, Geological Survey of Greenland, Øster Voldgade 10, DK-1350 Copenhagen K, Denmark, David C. Rex, Department of Earth Sciences, The University, Leeds LS2 9JT, UK, November 18th, 1988.

\section{Introduction}

Rifting and basin formation between Greenland and Norway was initiated during the early Carboniferous and continued until active sea floor spreading started in the Tertiary (Surlyk et al. 1981, 1984, 1986). In the Revdal area (fig. 1) Lower Permian continental sandstones were deposited on the Caledonian metamorphic basement (Kempter 1961, Collinson 1972). Syn-sedimentary faulting along the roughly N-S trending fault system in the area controlled the alluvial environment and the palaeocurrents (Larsen 1988, P.-H. Larsen \& L. Stemmerik, unpublished data).

Following a Mid-Permian period of erosion and peneplanation the Revdal area was transgressed in Late Permian times. Carbonates, evaporites and fine grained clastics of the Foldvik Creek Group were deposited in various shallow marine environments (Stemmerik 1985, Surlyk et al. 1986).

Stemmerik \& Sørensen (1980) observed in the Revdal area a number of thin lamprophyric dykes cutting the Lower Permian sediments but only parts of the Upper Permian sequence (figs 2, 4). The dykes all terminate at the base of the Upper Permian Karstryggen Formation limestone.
Clasts of isolated rock fragments of the lamprophyres are found immediately above the dyke terminations and Stemmerik \& Sørensen (1980) accordingly suggested a Late Permian intrusion age for the dykes. The dykes could thus represent the earliest magmatism related to the initial Permian rifting in this part of the North Atlantic. However, K-Ar age dating of 3 samples only gave Tertiary ages.

\section{Field observations}

More than 15 lamprophyric dykes are observed in the Revdal area. They are subvertical, $0.1-0.5 \mathrm{~m}$ wide and strike between $116^{\circ}$ and $154^{\circ} \mathrm{N}$ which is roughly parallel with the margins of the rift basin (Stemmerik \& Sørensen 1980).

\section{Eastern Revdal (locality A in Figs 2, 3)}

Five dykes are terminated by breccias at the boundary between the Upper Permian siliciclastic conglomerates of the Huledal Formation and the overlying limestones of the Karstryggen Formation. Isolated fragments of lamprophyric rocks, up to $30 \mathrm{~cm}$ in diameter are common in the basal $10 \mathrm{~m}$ of the Karstryggen Formation (fig. 5). 

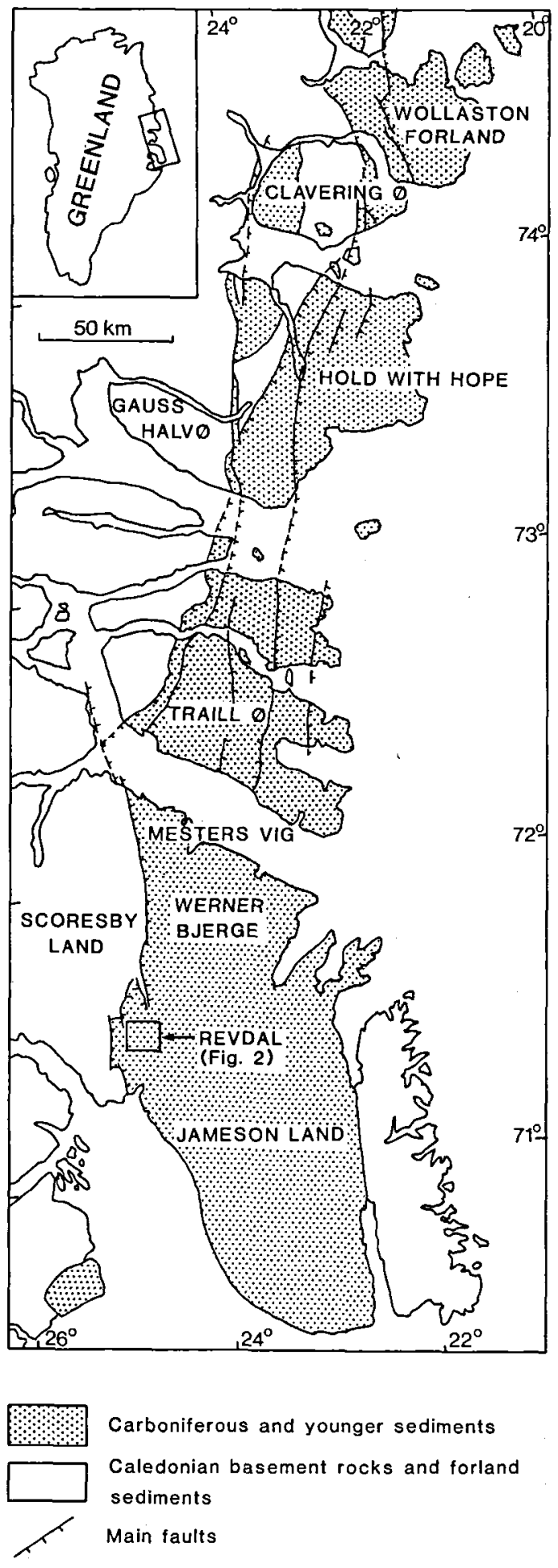

Fig. 1. Simplified geological map of central East Greenland. The location of Revdal area is indicated.
Western Revdal (locality B in figs 2, 3)

A dyke terminates within the Karstryggen Formation at the boundary between the gypsiferous Revdal Member and the overlying limestones. Also here lamprophyric rock fragments are common in a limestone conglomerate up to $5 \mathrm{~m}$ above the dyke termination.

Central Revdal (locality $\mathrm{C}$ in figs 2,3 )

This locality is not easily understood. Here four dykes terminate at the boundary between the Huledal Formation and the Karstryggen Formation as at locality A. However, fragments of very similar rocks (as observed in the field) are found in limestone conglomerates at levels 10,20 and 45 $\mathrm{m}$ above the boundary between the Huledal and Karstryggen Formations. Limestone conglomerates, which occasionally contain isolated lamprophyric rock fragments, even occur above the gypsiferous Revdal Member.

In addition to these dykes Stemmerik \& Sørensen (1980) also reported two dykes in the central Revdal area that intruded the entire Permian sequence. Based on the field observations Stemmerik \& Sørensen (1980) argued that the terminated dykes were of Late Permian age and were eroded and redeposited in the Upper Permian limestone conglomerates.

\section{$\mathrm{K}-\mathrm{Ar}$ mineral and whole rock determinations}

The three samples below were selected for $\mathrm{K}-\mathrm{Ar}$ age determination (see table 1):

\section{GGU 269176}

A lamprophyric dyke in eastern Revdal (locality A, figs 2,3) terminated at the base of the Karstryggen Formation. Biotite gave an age of 47 $+/-2 \mathrm{Ma}$. The sample also gave a whole rock age of $35+/-2 \mathrm{Ma}$, which may be the result of argon loss from this carbonate rich sample.

\section{GGU 269171}

A glassy lamprophyric rock fragment in the limestone conglomerate c. $10 \mathrm{~m}$ above dyke 269176 mentioned above gave a similar biotite age of 48 $+/-2 \mathrm{Ma}$. No whole rock age could be obtained. 


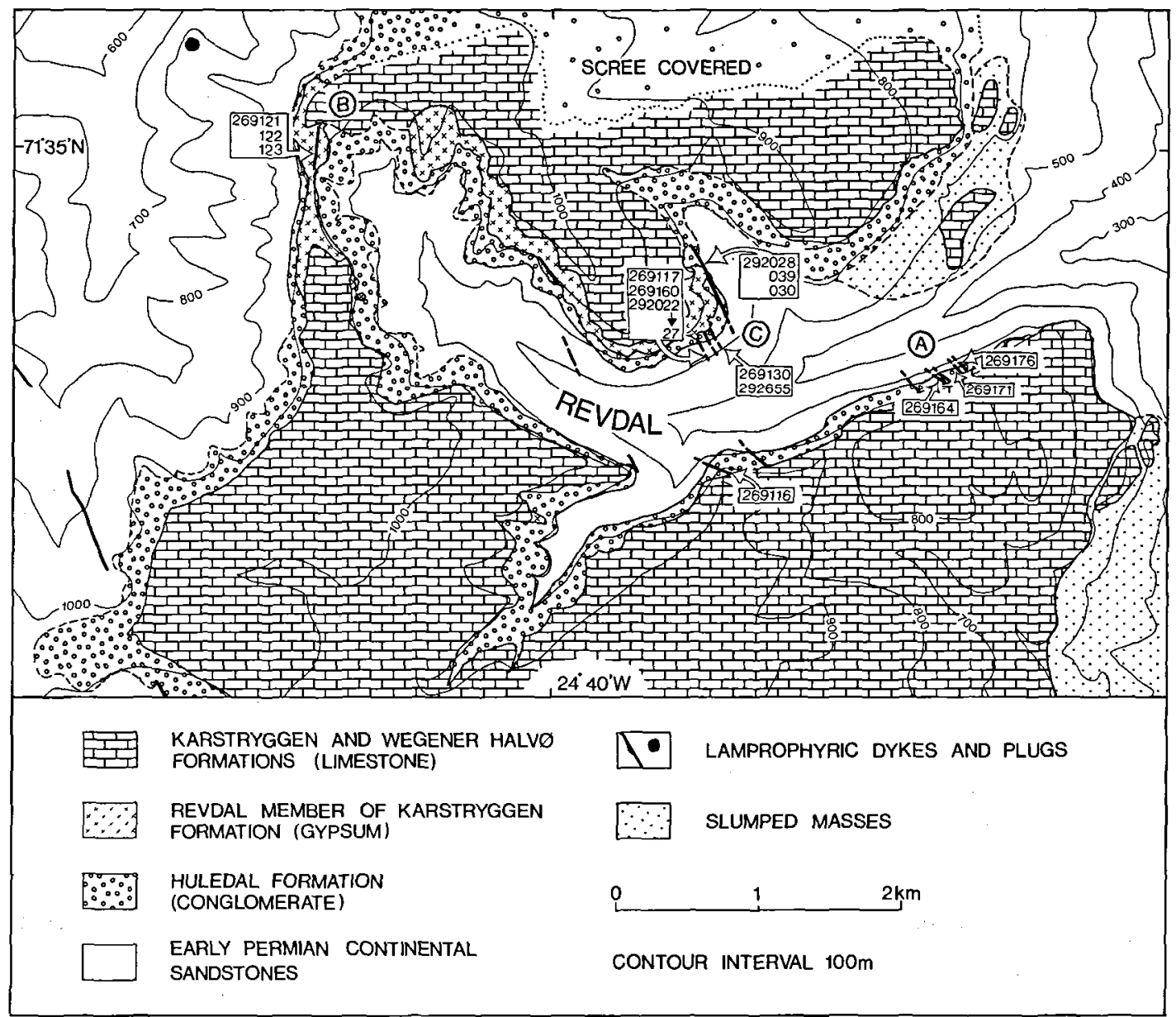

Fig. 2. Geological sketch of the Revdal area showing the distribution of the lamprophyre dykes. Encircled letters refer to locations discussed in the text and marked in figure 3 . Numbers refer to GGU sample numbers.

\section{GGU 269160}

A lamprophyric dyke from northern Revdal (locality $C$ in figs 2,3 ) with insufficient biotite for a biotite determination gave a whole rock age of 45 t/-2 Ma. Based on microprobe determination of the $\mathrm{K}_{2} \mathrm{O}$ content of a single perfect biotite crystal an age of $35 \mathrm{Ma}$ was indicated. As the average

W (B)

(C)

(A)

E

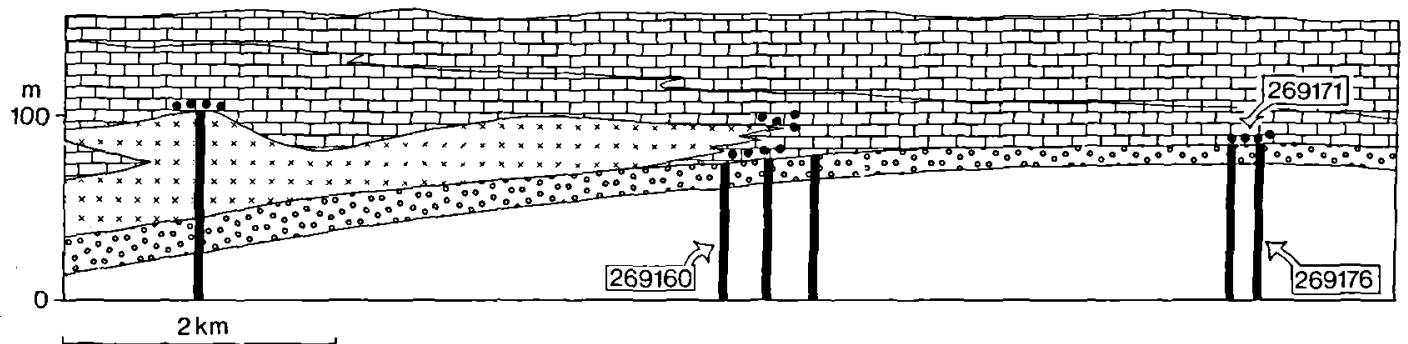

Fig. 3. Schematic section through Revdal based on Stemmerik (1980) showing the main spatial distribution of the lithological units and the relations between lamprophyre dykes and the host rocks. Ornamentation corresponds to figure 2 . The locations $A, B$ and $C$ discussed in the text are indicated. The numbers refer to the GGU sample numbers and the dated samples. 


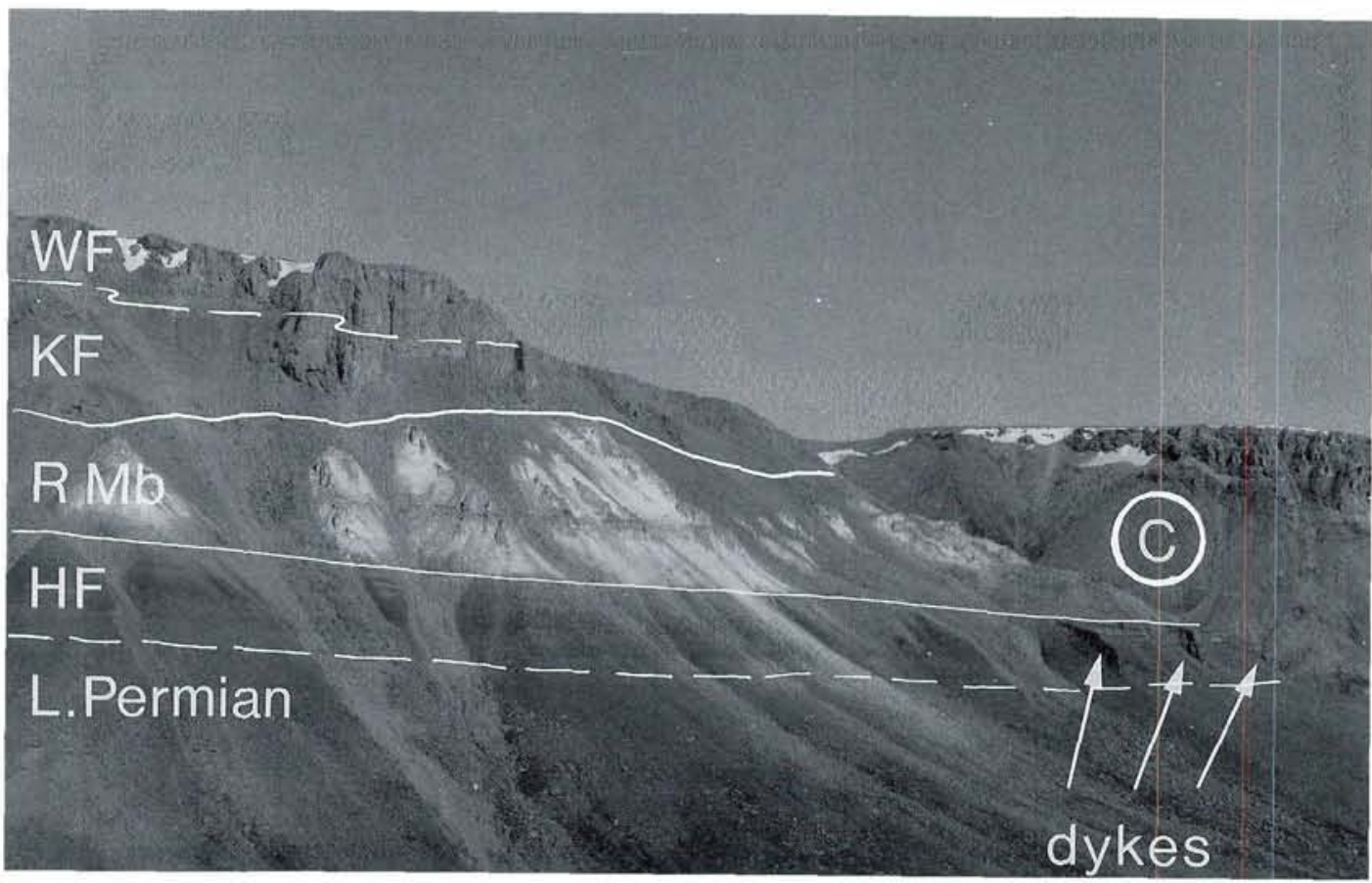

Fig. 4. Lamprophyre dykes cutting the Huledal Formation (HF) but terminated at the overlying gypsiferous Revdal Member (RMb) and limestones of the Karstryggen (KF) and the Wegener Halvø Formations (WF). Photo shows location $\mathrm{C}$ in figure 2 from the south-west.

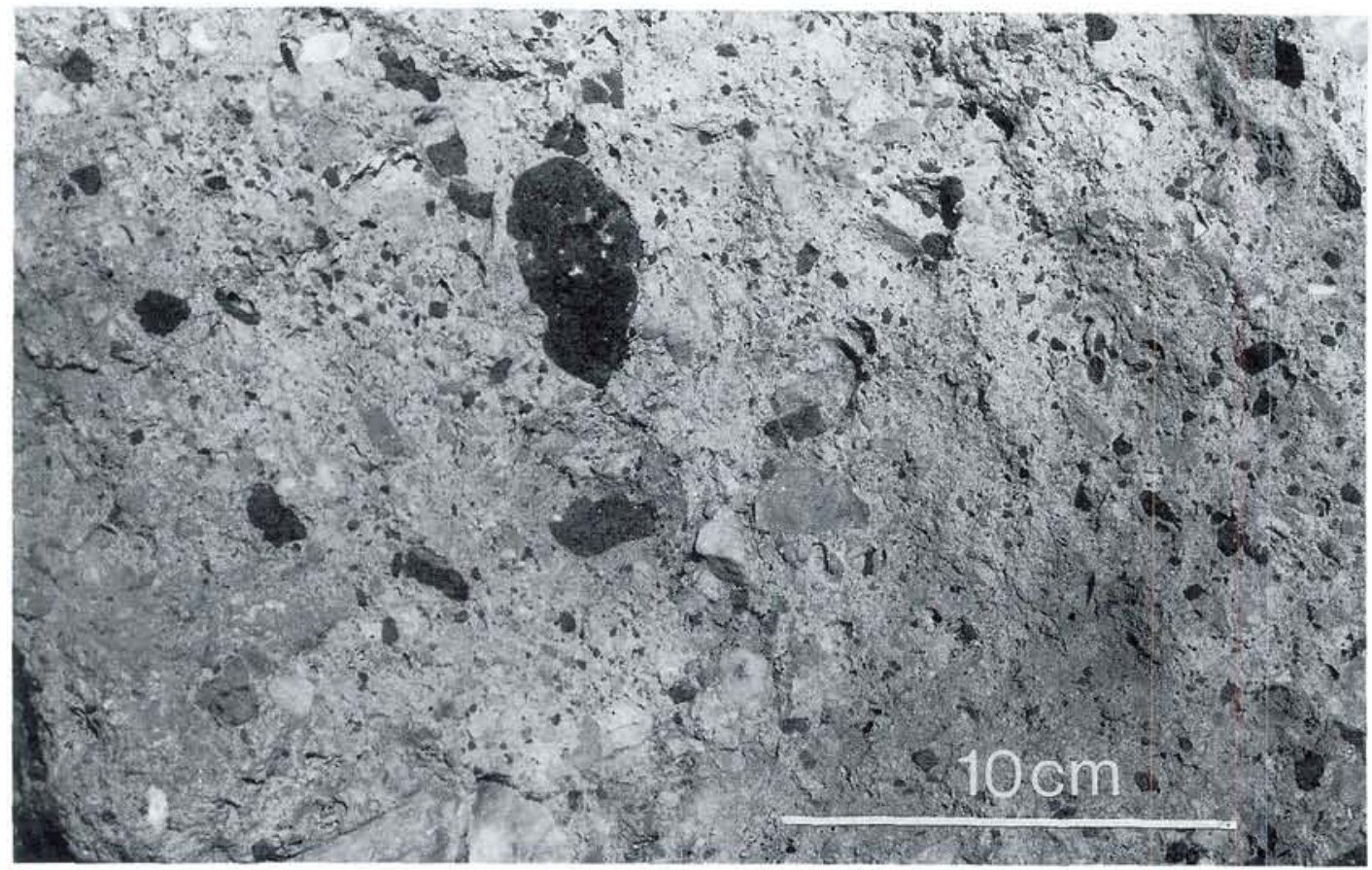

Fig. 5. Angular and rounded lamprophyric rock fragments (dark) in a limestone intraclast conglomerate at location B, western Revdal. 
Table 1. K-Ar isotopic data.

\begin{tabular}{|c|c|c|c|c|c|}
\hline $\begin{array}{l}\text { GGU } \\
\text { Sample no. }\end{array}$ & $\begin{array}{l}\text { Mineral/ } \\
\text { whole rock }\end{array}$ & $\% \mathrm{~K}$ & $\begin{array}{l}\text { Rad. }{ }^{40} \mathrm{Ar} \\
\mathrm{cm}^{3} / \mathrm{g} \times 10^{-5}\end{array}$ & $\%{ }^{40} \mathrm{Ar}$ rad. & Age Ma \\
\hline \multirow[t]{2}{*}{269176} & whole rock & 1.567 & 0.2142 & 40.6 & $35+1-2$ \\
\hline & biotite conc. & 4.530 & 0.8429 & 70.2 & $47+1-2$ \\
\hline 269171 & biotite conc. & 3.433 & 0.6471 & 72.1 & $48+1-2$ \\
\hline \multirow[t]{2}{*}{269160} & whole rock & 3.041 & 0.5393 & 61.1 & $45+1-2$ \\
\hline & biotite & $8.10^{*}$ & 1.1409 & 41.5 & $>35$ \\
\hline
\end{tabular}

* microprobe determination

$\mathrm{K}_{2} \mathrm{O}$ content of the biotite probably is lower the $35 \mathrm{Ma}$ age can only represent a minimum estimate.

Although only three samples have been analysed the good agreement between the various ages obtained suggests the dykes as well as the isolated rock fragments above the dykes to have closed their K-Ar systems at around $47+/-2 \mathrm{Ma}$. The ages represent either the time of intrusion or a major thermal event which has reset the ages.

\section{Petrography and chemistry}

Twenty-five samples of lamprophyric dykes and rock fragments from the Revdal area have been investigated petrographically and two have been analysed geochemically. All the investigated rocks are lamprophyres with variable amounts of glass and altered glass. Petrographically they include monchiquites, alnöitic monchiquites and fourchites (after Sørensen 1974, Rock 1987). The
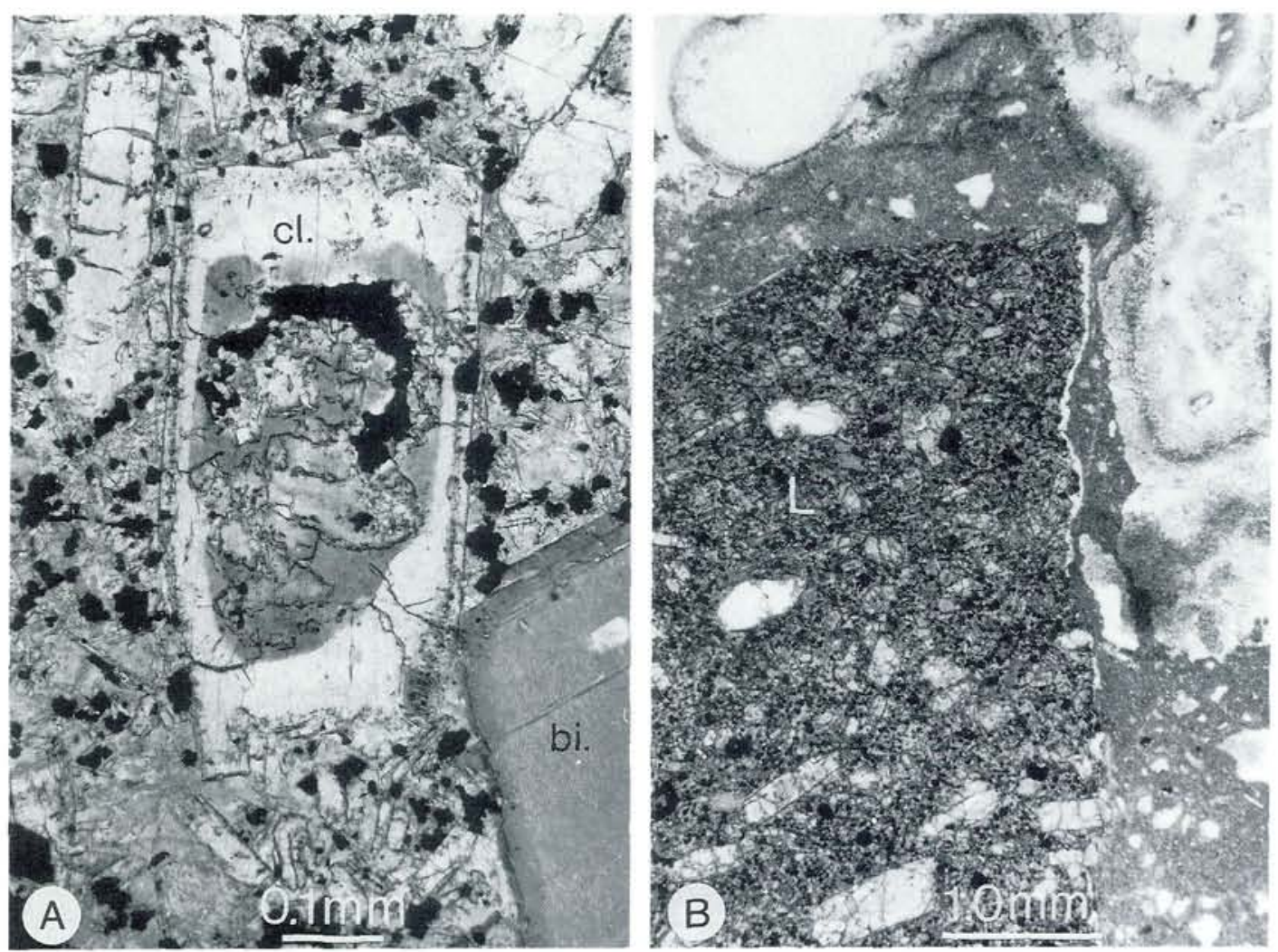

Fig. 6. A) Phenocryst of Ti-clinopyroxene with green salite or more sodic resorbed clinopyroxene core (cl.) and biotite phenocryst (bi.). The ground mass is rich in clinopyroxene, apatite needles, equidimentional oxides (magnetite ?) and altered glass (palagonite). GGU 269164, plane polarised light. B) Angular lamprophyre rock fragments in a limestone conglomerate. The clast is rich in hydrated glass in the groundmass, but shows no signs of cooling zonation. GGU 269171, plane polarised light. 
Table 2. Chemical compositions and CIPW norms of lamprophyric rocks from East Greenland.

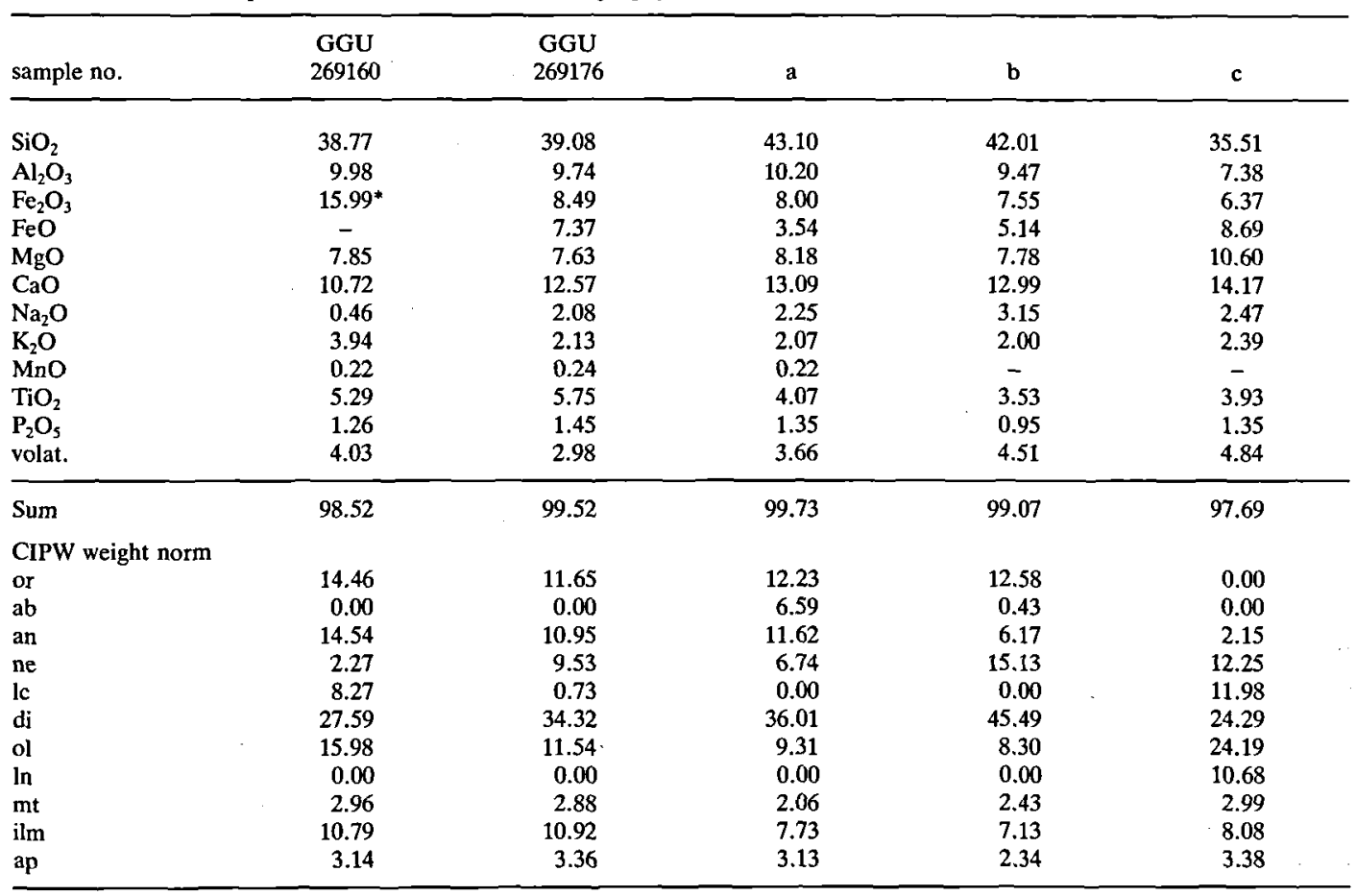

All $\mathrm{Fe}$ as $\mathrm{Fe}_{2} \mathrm{O}_{3}$

a) Tertiary trachybasalt, Kangerdlugssuaq (Nielsen 1987a, table 2, col. 5).

b) Tertiary monchiquite (GGU 98778), Scoresby Sund (Larsen \& Watt, 1985).

c) Tertiary alnöitic dyke (GGU 167116), Scoreby Sund (Larsen et al 1989)

most important phenocryst phase is clinopyroxene in a number of different generations. Large fragments of diopside often unzoned occur in all samples. Most samples also contain smaller euhedral pinkish Ti-augites that may be zoned. A few samples have complexely zoned megacrysts composed of resorbed green salite cores enclosed in diopsidic augite (fig. 6). Olivine, which is mostly pseudomorphed, is found in all monchiquites and alnöitic monchiquites (fourchites are olivine free monchiquites). Biotite or phlogopite phenocrysts occur in the alnöitic monchiquites. Euhedral spinel, probably Ti-rich magnetite occurs in all rocks. In addition many of the samples are rich in sedimentary xenoliths.

The groundmass is fine to medium grained. A few of the lamprophyric rock fragments and samples from the top of the dykes are rich in brown glass or palagonite. Clinopyroxene and apatite needles, small euhedral oxides and biotite flakes can be identified in the greyish presumably feld- spathoid rich matrix of the rocks. No evidence of major later thermal alteration is observed.

One extremely fine grained sample (GGU 269116) may be called a limburgite due to its high proportion of olivine phenocrysts, but it presumably has a composition rather similar to the rest of the investigated samples.

The two geochemically analysed samples (GGU 269160 and 269176) are both monchiquites, characterised by low $\mathrm{SiO}_{2}$ and $\mathrm{Al}_{2} \mathrm{O}_{3}$ and high $\mathrm{FeO}^{*}, \mathrm{TiO}_{2}, \mathrm{~K}_{2} \mathrm{O}$ and $\mathrm{P}_{2} \mathrm{O}_{5}$, but with very different $\mathrm{Na}_{2} \mathrm{O} / \mathrm{K}_{2} \mathrm{O}$ ratios (table 2). The CIPW norms show the undersaturated character by high $l c$ and in sample 269176 high ne. The mafic character is shown by the high ol contents. Chemically sample 269176 compares well with Tertiary dykes throughout East Greenland from the Kangerdlugssuaq area (Nielsen 1987a), the Scoresby Sund area (Larsen et al. 1989), the Mestersvig area, $80 \mathrm{~km}$ to the NE of Revdal (Kapp 1960) and the Hold with Hope area (Upton et al. 1984a, b). 


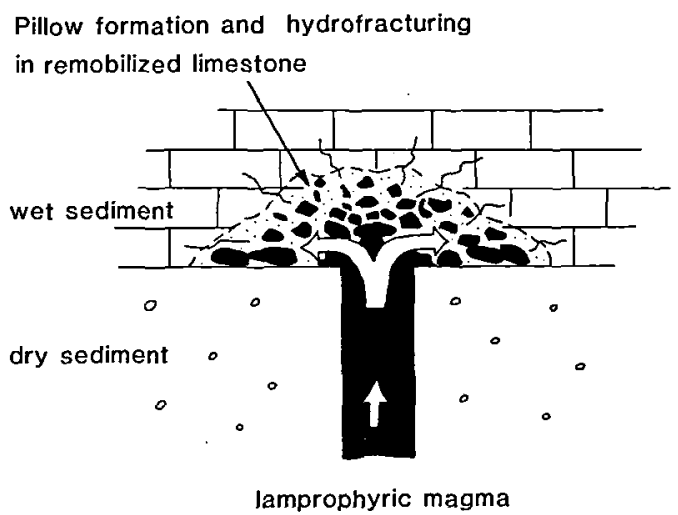

Fig. 7. The model of remobilisation, pillow formation and hydro-fracturing. See text for discussion.

In all cases the lamprophyric dykes postdate the tholeiitic magmatism related to the onset of sea floor spreading in this part of the North Atlantic around $55 \mathrm{Ma}$ ago (Brooks 1973, Nielsen 1987a,b). On a regional scale the alkaline magmatism has been dated to 45-30 Ma ago (Nielsen 1987a). No Permian or Mesozoic dykes of similar composition have hitherto been reported from the region.

Sample 269160 is somewhat different and has a high $\mathrm{K}_{2} \mathrm{O}$ and a very low $\mathrm{Na}_{2} \mathrm{O}$. Similar lamprophyres have not been reported from the Tertiary of East Greenland, but as described by Rock (1987) lamprophyre provinces often show a bimodal grouping with respect to the $\mathrm{K}_{2} \mathrm{O} / \mathrm{Na}_{2} \mathrm{O}$ ratio with a very $\mathrm{Na}_{2} \mathrm{O}$ poor and $\mathrm{K}_{2} \mathrm{O}$ rich group.

\section{Discussion}

Any model that explains the field observations and the geochemical data for these dykes must explain the Tertiary K-Ar age and the occurrence of lamprophyric rock fragments in the limestone conglomerates above the dykes. Assuming the field evidence to be correct the dykes emplaced in Late Permian times should have had their $\mathrm{K}$-Ar systems reset in Early Tertiary times. This is regarded unlikely for the following reasons:

(1) A thermal event that could be responsible for the resetting would probably also have destroyed the glass found in several of the dykes.
Both minerals and whole rock samples should have lost all argon produced from Permian to Tertiary times, which is regarded as unlikely.

(2) No thermal events are indicated by palynological and vitrinite analyses of the maturation of kerogen within the Permian sediments in the Revdal area (Surlyk et al. 1984, 1986, Piasecki 1985, Thomsen 1985). The thermal alteration index determined from the colours of sporomorphs indicate temperatures no higher than $100-200^{\circ} \mathrm{C}$ (S. Piasecki pers. comm. 1988).

Thus, assuming the dykes to be Tertiary, the occurrence of isolated lamprophyric rock fragments within the sediments above the dyke terminations has to be explained. The dykes have propagated through fairly compact rocks - siliceous sediments and gypsum - and terminate in limestones. The limestones presumably were water-rich compared to the more compact rocks below. Pillow formation and hydro-fracturing in remobilised limestone is believed to account for the lamprophyric rock fragments immediately above the dyke terminations (fig. 7). This however does not explain the lamprophyre rock fragment bearing breccias at levels 10,20 and $45 \mathrm{~m}$ above the dyke terminations at locality $\mathrm{C}$ in the central Revdal. These rock fragments were only studied in the field and none have been sampled for more detailed studies. Therefore they can not with certainty be correlated to the terminated dykes below as assumed by Stemmerik (1985).

As the analysis of one dyke compares well with other Tertiary dykes in East Greenland and as the $\mathrm{K}$-Ar ages also suggest a Tertiary age the dykes are most likely of Tertiary age. It is however clear that a closer examination of the rock fragments within the sediments above the dyke terminations is important for a definitive answer to the age of the dykes. It should be noted that palaeomagnetic investigations of the dykes have failed to give any consistent results even within single samples (C. Marcussen pers. comm. 1988).

This conclusion contradicts previous views given by Stemmerik \& Sørensen (1980) and Surlyk et al. $(1984,1986)$ identifying the Revdal dykes as the magmatic expression for the Permian rifting in this part of the North Atlantic. It would be surprising that such lamprophyres initiated the magmatism related to rifting. Lamprophyric magma types are generally emplaced during a protracted period after a major magmatic event 
as described from the Tertiary of West Greenland by Clarke et al. (1983) and from the Tertiary of East Greenland by Nielsen (1987a, b).

Acknowledgements. We are grateful to F. Surlyk, who initiated this study. V. Hermansen, B. S. Hansen, B. Thomas and J. Lautrup and the chemical laboratories are thanked for technical assistance. This communication is published with the authorisation of the Geological Survey of Greenland.

\section{Dansk Sammendrag}

Forekomst, petrografi og geokemi af lamprofyre gange i Revdal, Scoresby Land, Øst Grønland er beskrevet. Gangene intruderer nedre perm kontinentale sedimenter, men kun delvis $\emptyset v r e$ perm lagserien, idet de afsluttes ved basis af $\emptyset v r e$ perm marine kalksten tilhørende Karstryggen Formationen. I kalkstenskonglomerater umiddelbart over gangene findes isolerede bjergartsfragmenter af lamprofyrisk sammensætning. Dette er tidligere tolket som tegn på en perm instusionsalder, erosion og omlejring. K/Ar-dateringer af både gange og isolerede lamprophyre fragmenter $i$ sedimenterne ovenover viser derimod en Eocæn alder. Det konkluderes, at lamprofyrgangene er tertiære og aldrig har gennemsat øvre perm lagserien på grund af afkøling og hydro-frakturering ved mødet med de vandrige $\emptyset v r e$ perm sedimenter. Gangene antages at tilhøre en periode med alkalin magmatisme, som fulgte starten på havbundsspredninger $\mathrm{i}$ denne del af Nordatlanten for cirka 55 millioner år siden.

\section{Appendix}

\section{Analytical methods}

K-Ar dating: Decay constants used are as recommended by Steiger \& Jäger (1977). Potassium values quoted are the mean of three dissolutions. Concentrations were measured by flame photometry using a Corning Eel $450 \mathrm{Li}$ internal standard flame photometer. Argon was extracted in a glass vacuum system using a pure 38-argon spike (app. size $1 \times 10^{-5}$ s.c.c.). Argon isotopes were measured on a modified A.E.I. MS1O fitted with peak switching and digital output (Rex \& Dodson 1970).

Errors on the ages are $3 \%$ at the 2 sigma level, measured by replicate analyses. International standards were run at intervals throughout the period of analytical work.

The whole rock analyses were performed as described by Sørensen (1981).

\section{References}

Brooks, C.K. 1973: Tertiary of East Greenland - A volcanic and plutonic record of continental break-up. Artic Geology. Am. Ass. Petrol. Geol. Mem., 19, 150-160.

Clarke, D.B., Muecke, G.K., Pe-Piper, G. 1983: The lamprophyres of Ubekendt Ejland, West Greenland: prospects of renewed partial melting or extreme differentiation? Contrib. Mineral Petrol. 83, 1-2, 117-127.

Collinson, J.D. 1972: The Røde $\varnothing$ conglomerate of inner Scoresby Sund and the Carboniferous(?) and Permian rocks west of the Schuchert Flod. Meddr Grønland, 192, 6, 48 pp.

Kapp, H. 1960: Zur Petrologie der subvulkane zwischen Mesters Vig und Antarctic Havn (Ost-Grönland). Meddr Grønland, 153, 2, 203 pp.
Kempter, E. 1961: Die jungpalaeozoischen Sedimente von Süd-Scoresby Land (Ostgrönland, $711 / 2^{\circ} \mathrm{N}$ ), mit besonderer Berücksichtigung der kontinentalen sedimente. Meddr Grønland, 164, 1, 123 pp.

Larsen, L.M. \& Watt, W.S. 1985: Episodic volcanism during break up of the North Atlantic: evidence from the East Greenland Plateau basalts. Earth Planet Sci. Lett. 74, 105116.

Larsen, L.M., Watt, W.S. \& Watt. M. 1989: Geology and petrology of the Lower Tertiary plateau basalts of the Scoresby Sund region, East Greenland. Bull. Grønlands geol. Unders. 157, $156 \mathrm{pp}$.

Larsen, P.-H. 1988: Relay structures in a Lower Permian basement-involved extension system, East Greenland. $J$. Struct. Geol. 10, 3-8.

Nielsen, T.F.D. 1987a: Tertiary alkaline magmatism in East Greenland: a review. In: Fitton, J.G. \& Upton, B.G.J. (eds) Alkaline Igneous Rocks. Geol. Soc. Lond. Spec Publ. 30, 489-515.

Nielsen T.F.D. 1987b: Mafic dyke swarms in Greenland: a review, In: Halls, H.C. \& Farig, W.F. (eds). Mafic dyke swarms - intrusion, mechanics, geodynamic significance and global distribution. Geol. Ass. Can. Spec. Pap. 33, 349-360.

Piasecki, S. 1985: Palynological evaluation of the regional thermal maturation of Carboniferous to Tertiary sediments in central East Greenland. Gronland geol. Unders. Unpublished Internal Rep., 51 pp.

Rex, D.C. \& Dodson, M.H. 1970: Improved resolution and precision of argon analysis using a MS1O mass spectrometer. Eclog. Geol. Helv. 63, 275-280.

Rock, N.M.S. 1987: Nature of lamprophyres. In: Fitton, J.G. \& Upton, B.G.J. (eds), Alkaline Igneous Rocks. Geol. Soc. Lond. Spec. Publ. 30, 191-226.

Steiger, R.H. \& Jäger, E. 1977: Subcommission on geochronology: convention on the use of decay constants in geo- and cosmo-chronology. Earth Planet. Sci. Lett. 36, 359-362.

Stemmerik, L. 1980: Observations on Upper Permian sediments in southern Scoresby Land, East Greenland. Rapp. Grønlands geol. Unders. 100, 105-107.

Stemmerik, L. 1985: Sedimentare og diagenetiske processer i et karbonatlevaporit domineret subtidalt-supratidalt aflejringsmiljø, Øvre Perm, Østgrønland. Ph.D. Thesis, University of Copenhagen, $200 \mathrm{pp}$.

Stemmerik, L. \& Sørensen, M. 1980: Upper Permian dykes in southern Scoresby Land, East Greenland. Rapp. Grønlands geol. Unders. 100, 108.

Surlyk, F., Clemmensen, L.B. \& Larsen, H. C. 1981: PostPalaeozoic evolution of the East Greenland continental margin. Bull. Can. Petrol. Assoc. Mem. 7, 611-645.

Surlyk, F., Hurst, J.M., Piasecki, S., Rolle, F., Scholle, P.A., Stemmerik, L. \& Thomsen, E. 1986: The Permian of the Western Margin of the Greenland Sea - A future exploration target. In: Halbouty, M.T. (ed) Future petroleum provinces of the world. Am. Ass. Petrol. Geol. Mem. 40, 629-659.

Surlyk, F., Piasecki, S. Rolle, F., Stemmerik, L. Thomsen, E. \& Wrang, P. 1984: The Permian basin of East Greenland. Petroleum Geology of the North European Margin. Norwegian Petroleum Society, 303-315.

Sørensen, H. 1974: Glossary of alkaline and related rocks. In: Sorensen H. (ed). The Alkaline Rocks. John Wiley \& Sons. London, 558-577.

Sørensen, I. 1981: A calculated background correction method for XRF. Spec. Acta, 36B, 243-249.

Thomsen, E. 1985: A coalification study of Upper PalaeozoicMesozoic deposits from central East Greenland. Grønland geol. Unders., Unpublished Internal Rep., 55 pp.

Upton, B.G.J., Emeleus, C.H. \& Beckinsale, R.D. 1984a: Petrology of the northern East Greenland Plateau Basalts: 
evidence from Hold with Hope and Wollaston Forland. $J$. Petrol. 25, 151-184.

Upton, B.G.J., Emeleus, C.H, Beckinsale, R.D. \& Macintyre, R.M. 1984b: Myggbukta and Kap Broer Ruys: the most northerly of East Greenland Tertiary centres (?). Mineral. Mag. 48, 323-343. 